\title{
HUBUNGAN FAKTA GEOPOLITIK DENGAN PERENCANAAN BAHASA
}

\author{
Yani Suryani \\ KK Ilmu Kemanusiaan \\ Fakultas Seni Rupa dan Desain Institut Teknologi Bandung \\ Surel: yanisuryani80@gmail.com
}

\begin{abstract}
ABSTRAK
Geopolitik berperan penting terhadap eksistensi sebuah bahasa dan bangsa. Perencanaan bahasa di sebuah negara menjadi penting karena dapat berperan menjaga keutuhan bangsa, melancarkan hubungan diplomatik, dan melakukan ekspansi bahasa bagi kebutuhan industri dan ekonomi. Dari negara-negara yang terdapat di lima benua, didapat simpulan bahwa geopolitik sebuah negara berperan besar terhadap perencanaan bahasa di negara tersebut. Negara yang situasi geopolitiknya stabil dapat melakukan ekspansi bahasa ke negara lain. Sementara itu, negara dengan geopolitik yang masih bergejolak sangat memerlukan perencanaan bahasa yang matang.
\end{abstract}

Kata kunci: geopolitik, perencanaan bahasa, ekspansi

\section{ABSTRACT}

Geopolitics is vital to the existence of a language and nation. Language planning in a country is important because it may contribute to the process of maintaining the integrity of the nation, keeping diplomatic relations, and expanding language for the needs of industry and economy. Of the countries in the five continents, a conclusion was obtained that the geopolitics of a state contributes significantly to the language planning of the country. Countries with stable geopolitical situation can expand their language to other countries. Meanwhile, countries with highly volatile geopolitical condition still require a careful language planning.

Keywords: geopolitics, language planning, expansion

\section{PENDAHULUAN}

Selama lebih dari sepuluh tahun terakhir telah terjadi peningkatan minat dan aktivitas perencanaan dan pengembangan bahasa. Peristiwa yang terkenal di antaranya Survei Penggunaan Bahasa dan Pengajaran Bahasa di Afrika Timur, Konferensi Permasalahan Bahasa dalam Perkembangan Negara (Fishman, Ferguson, dan Das Gupta, 1968), Konferensi Proses Perencanaan Bahasa (Rubin dan Jernudd, 1971), Proyek Penelitian Internasional tentang Proses Perencanaan Bahasa, Konferensi Sosiolinguistik Berorientasi Survei Bahasa (Ohannessian 1971), dan Konferensi Sosiolinguistik terbaru yang diadakan di Georgetown University. Adanya perencanaan bahasa di sebuah negara menjadi penting karena perencanaan bahasa berperan untuk menjaga keutuhan bangsa, hubungan diplomatik, dan melakukan ekspansi bahasa bagi kebutuhan industri dan ekonomi. Peren- canaan bahasa menjadi hal penting karena menyangkut eksistensi sebuah bangsa. Karena itulah, geopolitik sebuah negara juga menunjang perencanaan bahasa yang bersangkutan dan eksistensi bahasa dan bangsa tersebut.

Berdasarkan latar belakang di atas, dibuatlah rumusan masalah sebagai berikut.

1. Bagaimana hubungan fakta geopolitik dengan perencanaan bahasa di negaranegara yang terdapat di lima benua?

2. Bagaimana hubungan fakta geoolitik dengan perencanaan bahasa di Indonesia?

Adapun tujuan yang hendak dicapai

adalah

1. Menjelaskan hubungan fakta geopolitik dengan perencanaan bahasa di negaranegara yang terdapat di lima benua.

2. Menjelaskan hubungan fakta geopolitik dengan perencanaan bahasa di Indonesia. 


\section{TINJAUAN PUSTAKA}

\section{Pengertian Geopolitik}

Geopolitik berasal dari dua kata yaitu geo dan politik. Geo artinya Bumi atau Planet Bumi, sedangkan politik selalu berhubungan dengan kekuasaaan dan pemerintahan. Dalam studi hubungan internasional, geopolitik merupakan suatu kajian yang melihat masalah/hubungan internasional dari sudut pandang ruang atau geosentrik. Pengertian geopolitik dapat lebih disederhanakan lagi yaitu suatu studi yang mengkaji masalah geografi, sejarah, dan ilmu sosial dengan merujuk pada politik internasional. Geopolitik diperlukan oleh setiap negara di dunia untuk memperkuat posisinya di antara negara lain, untuk memperoleh kedudukan yang penting di antara bangsa, atau secara lebih tegas lagi untuk menempatkan diri pada posisi yang sejajar dengan negara maju. Keadaan geografi suatu negara sangat memengaruhi berbagai aspek dalam penyelenggaraan negara tersebut, seperti pengambilan keputusan, kebijakan politik luar negeri,dan hubungan perdagangan. Kita ambil contoh negara Indonesia. Sebagai negara kepulauan yang terletak di antara dua benua dan dua samudera serta berada di Garis Khatulistiwa dan dilewati oleh Geo Stationary Satelite Orbit (GSO), Indonesia membuat konsep geopolitik yang dinamakan Wawasan Nusantara (UNY, 2005: 4). Wawasan nusantara menjadi landasan penentuan kebijaksanaan politik negara. Misalnya, untuk tujuan pengamanan negara baik secara fisik maupun sosial, dipersiapkanlah daerah penyangga yang berbatasan dengan Malaysia dan pembangunannya dipersiapkan secara sistematis.

\section{Perencanaan Bahasa}

Istilah perencanaan bahasa atau language planning pertama kali diperkenalkan oleh Haugen. Dalam artikelnya, Haugen (1959: 2) mengemukakan perencanaan bahasa adalah suatu usaha untuk membimbing perkembangan bahasa ke arah yang diinginkan para perencana. Usaha-usaha tersebut misalnya menyiapkan ortografi, penyusunan tata bahasa dan kamus yang normatif sebagai panduan untuk penulis dan pembicara dalam suatu komunitas bahasa yang tidak homogen (Cooper, 1989:29, Moeliono, 1981:5).

Dalam bukunya Advance in Language Planning, Fishman (1977) menekankan perencanaan bahasa dapat dikelompokkan menjadi dua bagian, yaitu perencanaan status dan perencanaan korpus. Perencanaan status adalah pemberian kedudukan yang jelas pada suatu bahasa, yaitu sebagai bahasa resmi, bahasa negara, atau bahasa nasional. Tindakan ini menyangkut bagaimana peran pemerintah, bagaimana payung hukumnya, bagaimana pelaksanaan teknisnya yang terkait dengan penguasaan dasar pemakaian, penyebaran pemakaian, pemupukan sikap pemakai, dan deskripsi bahasa tersebut. Perencanaan korpus adalah usaha kodifikasi bahasa dalam rangka penyempurnaan bahasa tersebut sehingga bisa dipakai secara mantap baik secara lisan maupun tulis. Aspek -aspek yang dirancang adalah huruf, ejaan, lisan, tulis, kosakata, istilah, kamus, buku teks, laras, sastra, dan bahan pengajaran bahasa di lembaga-lembaga pendidikan.

Anton M. Moeliono dalam disertasinya "Pengembangan dan Pembinaan Bahasa: Ancangan Alternatif di dalam Perencanaan Bahasa" mengungkapkan perencanaan bahasa (language planning) merupakan kegiatan dasar, baik bagi usaha pengembangan bahasa (language development) maupun bagi usaha pembinaan bahasa (language cultivation). Pemahaman terhadap makna perencanaan bahasa perlu ditinjau kembali karena ada masalah kebahasaan yang pemecahannya tidak bergantung pada perencanaan, tetapi pada putusan garis haluan (policy decision).

Perencanaan bahasa (language planning) sebagai salah satu bagian kebudayaan menjadi sorotan yang penting juga terhadap keberadaan suatu negara. Dengan adanya penjajahan, beberapa bahasa asli banyak yang punah dan tergantikan dengan bahasa asing yang dibawa penjajah. Selain itu, derasnya arus teknologi saat ini memungkinkan tergerusnya bahasa asli. Di sinilah peren-canaan bahasa berperan penting untuk menjaga kelestarian bahasa asli.

\section{METODE PENELITIAN}

Metode yang dilakukan dalam penelitian ini adalah studi pustaka. Peneliti menelusuri sumber referensi mengenai geopolitik dan perencanaan bahasa di beberapa negara melalui internet dan buku di perpustakaan. 


\section{HASIL DAN PEMBAHASAN}

\section{Fakta Geopolitik dan Perencanaan Bahasa di Lima Benua}

Berdasarkan sumber referensi yang ditemukan, dipilihlah lima wilayah dunia yang menjadi objek penelitian sesuai dengan ketetapan Konferensi Umum UNESCO. Kelima wilayah tersebut memiliki studi kasus yang berbeda. Wilayah tersebut adalah Afrika, Arab (kira-kira daerah Maghreb dan Timur Tengah), Asia dan Pasifik, Eropa dan Amerika Utara (termasuk Kanada, Israel, dan beberapa negara bekas Uni Soviet tetapi tidak termasuk Amerika Serikat), dan Amerika Latin dan Karibia. Penelitian dilakukan di wilayah tersebut karena memiliki situasi sosiolinguistik yang berbeda sehingga diha-rapkan perencanaan bahasa yang dilakukan pun berbeda dari satu wilayah ke wilayah lain.

\section{a. Amerika}

Sebagai negara yang dikelilingi daratan (land lock country) dan pernah dijajah, negara-negara di Benua Amerika cukup memiliki satu bahasa dengan dominasi terbesar yaitu bahasa Inggris, Perancis, dan Portugis di setiap wilayah bekas jajahan. Perlu menjadi catatan bahwa Amerika memiliki banyak campuran bahasa imigran. Namun, bahasa Amerindian dan bahasa Inggris tidak termasuk ke dalam bagian anggota UNESCO yang ada di Amerika. Selain itu, dalam penge-lompokan UNESCO, Kanada termasuk bagian dari Eropa. Sebagai bagian dari bekas jajahan Eropa dan Amerika, bahasa asli Amerika mulai menghilang. Walaupun tidak semuanya seperti itu, misalnya ba-hasa Quechua, secara umum dapat dika-takan bahwa bahasa Pre-Columbian di Amerika terancam punah. Bahasa Karibian memiliki kasus yang khusus juga. Di beberapa wilayahnya masih menggunakan beberapa bahasa kreol.

Perencanaan bahasa di negaranegara Amerika akan muncul ketika mempertanyakan penjagaan bahasa Amerindian. Disebutkan bahwa pada abad ke-16, orangorang di Amerika menggunakan 900 bahasa Amerindian yang berbeda, sedang-kan pada saat ini tinggal 50 bahasa yang digunakan dalam kehidupan sehari-hari (Malherbe 1995:254). Kasus ini serupa dengan kasus yang dialami di Australia dan Selandia
Baru, yaitu bahasa Inggris sangat mendominasi sehingga bahasa asli daerah itu terancam punah. Amerika dan Australia memiliki karakteristik bahasa yang sama. Ketika bangsa Eropa menjajah kedua benua itu, penduduk aslinya masih sangat sedikit sehingga ketika Eropa datang dengan pasukan yang banyak, secara tidak langsung fakta ini menyebabkan budaya dan bahasa asli menjadi lemah dan tergeser. Hal ini pun secara otomatis me-musnahkan bahasa Ameridian. Sebalik-nya, di Asia dan Afrika, bangsa Eropa menjadi minoritas sehingga bahasa mereka tidak mampu menyebar dengan cepat seperti yang terjadi di Amerika, Australia, dan Oceania.

\section{b. Eropa}

Secara geopolitik, negara-negara di Benua Eropa sebagian besar merupakan negara maju dengan sistem ekonomi dan politik yang stabil. Oleh karena itu, di Benua Eropa banyak negara yang memiliki bahasa nasional sendiri seperti Portugal dengan bahasa Portugis, Swedia dengan bahasa Swedia, dan Yunani dengan bahasa Yunani. Namun, Eropa juga memiliki beberapa bahasa minoritas seperti bahasa Celtic di Inggris, bahasa Basque di Perancis dan Spanyol, Katalan di Spanyol, Breton di Perancis, Saami di bagian utara Skandinavia, dan banyak lagi (tentang topik ini, lihat lebih lanjut Lunden, 1993). Harus diingat juga bahwa negara-negara di Eropa memiliki komunitas imigran yang sangat banyak. Salah satu tugas peren-canaan bahasa yang terpenting di Eropa mungkin salah satunya dengan penguatan bahasa minoritas yang terdapat di sana. Hal ini sedang dilakukan di Uni Eropa, di sana daerah transnasional dipandang lebih penting daripada daerah yang mempunyai penduduk tradisional. Daerah yang digambarkan oleh Uni Eropa umumnya memiliki bahasa minoritas seperti bahasa Saami atau Catalan.

Beberapa tahun lalu, Uni Soviet dan Yugoslavia menjadi subjek dalam berbagai diskusi yang berhubungan dengan perencanaan bahasa. Negara -negara tersebut merupakan negara bekas jajahan yang memiliki sejumlah populasi berbeda yang berbicara dengan bahasa yang berbeda. Di Uni Sovyet, sejumlah bahasa daerah berada di bawah tekanan bahasa Rusia. Setelah Uni 
Sovyet runtuh, bahasa yang dipakai di berbagai negara bekas republik tersebut diharapkan dapat mem-bawa angin segar dalam kehidupan berbahasa. Perlu dicatat juga bahwa negara-negara yang baru merdeka tersebut juga memiliki bahasa sendiri. Di negara bekas jajahan Yugoslavia, berdiri negara-negara baru. Namun sayangnya, negara-negara ini masih dilanda berbagai konflik internal sehingga hal-hal yang berkaitan dengan kebahasaan belum dapat diteliti lebih lanjut.

\section{c. Asia}

Berbeda dari yang terjadi di Amerika dan Australia, kolonial Eropa tidak bisa bergerak cepat memengaruhi budaya dan bahasa negara -negara jajahan-nya. Di Asia mereka hanya mendirikan benteng dan berdagang tetapi tidak berhasil mempengaruhi budaya asli. Jadi, meskipun bahasa Eropa hadir di negara -negara Asia, bahasa itu tidak digunakan secara luas dalam kehidupan sehari-hari kecuali dalam sektor tertentu seperti dunia bisnis. Hal ini bisa kita lihat terjadi di Jepang dan Cina. Namun, ada juga negara-negara yang menggunakan bahasa Eropa sebagai bahasa resmi negara. Banyak juga negara di Asia yang setingkat dengan Eropa tapi memiliki bahasa nasional sendiri, misalnya bahasa Jepang, China, dan bahasa Thai di Thailand. Hal itu tidak berarti di Asia tidak terdapat bahasa minoritas. Di beberapa negara seperti Cina, Nepal, dan Laos banyak terdapat puluhan bahasa minoritas. Bahasa yang terancam punah juga dapat ditemukan di Siberia dan Arktik.

Arab memiliki kasus tersendiri. Bahasa Arab merupakan bahasa yang dominan. Bahasa ini memiliki berbagai variasi yang pengucapannya berbeda antara satu negara dengan negara yang lain. Sementara itu, bahasa Arab standar digunakan di berbagai negara. Dari beberapa kasus tadi, tampaknya peran bahasa Eropa tidak terlalu penting dalam isu perencanaan bahasa di Asia.

\section{d. Australia}

Seperti telah dipaparkan sebelumnya, situasi bahasa di Australia dan Selandia Baru mirip dengan bahasa Inggris di Amerika. Walaupun Selandia Baru mempunyai populasi Maori yang sangat penting, bahasa dan budayanya terancam punah. Di Pasifik, bahasa asli masyarakat Melanesia dan Polinesia dapat bertahan lebih baik daripada di Amerika dan Australia. Bahasa asli memang tidak begitu terancam punah, tapi kehadiran bahasa Eropa di Oceania juga menjadi faktor yang patut diperhitungkan. Bahasa Pasifik benarbenar dalam bahaya kepunahan karena dalam faktanya bahasa itu hanya digunakan oleh sedikit orang dan jarang diakui secara resmi.

\section{e. Afrika}

Di Afrika terdapat ribuan bahasa asli. Namun, ada empat kelompok bahasa besar yang berasal dari benua ini.

a. Kelompok bahasa Afro-Asiatik yang terdiri atas lebih dari 240 bahasa dan 285 juta penutur yang tersebar luas di sepanjang Afrika Utara, Afika Timur, Sahel, dan Asia Barat Daya.

b. Kelompok bahasa Nil-Sahara terdiri atas lebih dari seratus bahasa yang dituturkan oleh 30 juta penutur. Bahasa ini kebanyakan dipakai di Chad, Sudan, Ethiopia, Uganda, Kenya, dan sebelah utara Tanzania.

c. Kelompok bahasa Niger-Kongo. Kelompok bahasa ini merupakan kelompok bahasa yang terbesar dari segi jumlah dan digunakan di sebagian besar Afrika bagian sub-Sahara.

d. Kelompok bahasa Khoisan yang terdiri atas 50 bahasa dan dituturkan di sebelah selatan Afrika oleh sekitar 120 ribu jiwa.

Dari keempat kelompok bahasa

tersebut, bahasa Khoisan termasuk bahasa yang terancam punah.

Bahasa Arab yang banyak digunakan di daerah Afrika Utara tidak dianggap sebagai bahasa Afrika. Begitu juga de-ngan kondisi bahasa Eropa yang hadir di manamana karena Afrika merupakan daerah bekas jajahan Eropa. Di Afrika Utara, bahasa Arab sering dijadikan ba-hasa resmi dan kadang-kadang bersaing dengan bahasa Perancis. Di beberapa negara, bahasa Eropa juga ada yang digunakan menjadi bahasa resmi negara tersebut. Hal tersebut bertentangan de-ngan kondisi di Australia dan Amerika. Memang, bahasa Eropa penting sebagai bahasa kedua di Afrika, tetapi jumlah penutur bahasa pertama masih sangat terbatas. Dalam hal ini, Afrika me- 
nyerupai Asia. Afrika merupakan negara dengan jumlah penutur bahasa asli yang sangat tinggi. Bahkan, penutur bahasa Eropa ada yang kurang dari $10 \%$ penduduk yang ada. Hal ini karena karakteristik Afrika yang mempunyai batas-batas budaya tetapi tidak tumpang tindih dengan geografi yang ada. Situasi kebahasaan di Afrika sangatlah buruk. Banyak negara bekas jajahan yang telah mendapat bahasa resmi tetapi berasal dari bahasa poskolonial yang sangat tidak terkenal di kalangan penduduk.

Akibatnya, banyak bahasa nasional di negara-negara Afrika yang tidak berfungsi sebagai bahasa resmi karena bahasa tersebut tidak dimengerti penduduknya. Karena itulah, peren-canaan bahasa di Afrika sangatlah diperlukan.

\section{f. Fakta Geopolitik dan Perencanaan Bahasa di Indonesia}

Sebagai negara kepulauan yang terdiri atas berbagai suku bangsa, Indonesia juga mempunyai 748 bahasa daerah yang digunakan oleh penuturnya sebagai bahasa ibu (Depdiknas, 2009). Perencanaan bahasa di Indonesia dipelopori oleh para pemuda yang tergabung dalam organisasi Budi Utomo ketika mereka mengumandangkan Sumpah Pemuda pada 28 Oktober 1928. Salah satu butir sumpah pemuda tersebut adalah "Kami menjunjung bahasa persatuan, bahasa Indonesia". Pernyataan menjunjung tinggi bahasa persatuan mengandung makna:

1. Pengutamaan bahasa Indonesia di atas kepentingan bahasa-bahasa lain.

2. Memberikan hak hidup bahasa-bahasa daerah yang ada di Indonesia

3. Memberi peluang penggunaan ba-hasa asing untuk keperluan tertentu.

Dari situlah dimulai babak baru sejarah bahasa di Indonesia. Bahasa di Indonesia yang terdiri atas 748 bahasa daerah bersepakat untuk menggunakan bahasa Indonesia sebagai bahasa persatuan. Bahasa Indonesia diambil dari salah satu ragam bahasa Melayu (Kridalaksana, 1991). Dasar yang dipakai adalah bahasa Melayu Riau dari abad ke -19. Dalam perkembangannya, bahasa Indonesia mengalami perubahan akibat penggunaannya dan menyebabkan berbedanya bahasa Indonesia saat ini dari ragam bahasa Melayu yang digunakan di Riau dan Semenanjung Malaya.

Sejak itulah, bahasa Indonesia mempunyai fungsi dan kedudukan tersendiri dalam kehidupan berbangsa dan bernegara. Bahasa Indonesia berfungsi sebagai bahasa nasional dan bahasa negara. Fungsi bahasa tersebut dapat dirinci 1 sebagai berikut.

Bahasa Indonesia sebagai bahasa nasional memiliki beberapa fungsi, yaitu

1. lambang kebanggaan

2. lambang identitas nasional

3. alat perhubungan antarwarga, antar daerah, antarbudaya

4. alat yang memungkinkan pe-nyatuan berbagai suku bangsa dengan latar budaya dan bahasanya masing-masing.

Sebagai bahasa Negara, bahasa Indonesia memiliki beberapa fungsi pula,

1. bahasa resmi kenegaraan

2. bahasa pengantar di dalam dunia pendidikan

3. alat perhubungan pada tingkat nasional untuk kepentingan peren-canaan dan pembangunan

4. alat pengembang kebudayaan, ilmu pengetahuan, dan teknologi.

Secara perencanaan status, pemerintah Indonesia telah memberikan payung hukum yang jelas mengenai bahasa Indonesia. Pada Undang-Undang Dasar 1945 Pasal 36 tertulis dengan jelas bahwa "Bahasa Negara adalah Bahasa Indonesia". Dengan payung hukum tersebut, kedudukan bahasa Indonesia sebagai bahasa nasional menjadi kuat adanya. Hal itu diperkuat juga dengan didirikannya Pusat Bahasa yang bertugas untuk mengembangkan, membina, dan melindungi bahasa dan sastra Indonesia.

Pusat Bahasa bertugas menangani masalah kebahasaan dan kesastraan di Indonesia. Selain itu, lembaga ini juga mempunyai tugas melaksanakan pengembangan, pembinaan, serta pelindungan bahasa dan sastra Indonesia.

Dalam menjalankan tugasnya, lembaga ini menjalankan beberapa fungsi, yaitu 
1. penyusunan kebijakan teknis, rencana dan program pengembangan, pembinaan, serta pelindungan bahasa dan sastra Indonesia,

2. pelaksanaan pengembangan, pem-binaan, serta pelindungan bahasa dan sastra Indonesia,

3. pemantauan, evaluasi, serta pelaporan pelaksanaan pengembangan, pemb-inaan, dan pelindungan bahasa dan sastra Indonesia, dan

4. pelaksanaan administrasi Badan Pengembangan dan Pembinaan Bahasa.

Lembaga inilah yang kini bertugas menjalankan perencanaan bahasa dari sisi perencanaan korpus. Dalam perencanaan korpus ini, Pusat Bahasa telah menerbitkan beberapa pedoman, di antaranya:

KBBI (Kamus Besar Bahasa Indonesia) - edisi 4

Kamus istilah - kamus khusus untuk bidang ilmu dasar, antara lain (fisika, kimia, matematika, dan biologi); ilmu terapan (kedokteran, filsafat, hukum, bahasa, sastra, komunikasi massa, pendidikan, agama, dan lain-lain). Kamus istilah ini adalah kerja sama antara Pusat Bahasa, pakar bidang ilmu, dan Majelis Bahasa Brunei Darussalam-IndonesiaMalaysia (MABBIM)

Tesaurus Bahasa Indonesia Pusat Bahasa sebagai sumber padanan kata.

Uji kemahiran berbahasa atau proficiency test yang disebut dengan UKBI (Uji Kemahiran Berbahasa Indonesia) dan mengembangkan bahan ajar BIPA (Bahasa Indonesia untuk Penutur Asing). Rancangan Undang-Undang Bahasa yang akan mendudukkan tiga jenis bahasa di Indonesia, yaitu bahasa daerah sebagai bahasa ibu, bahasa Indonesia sebagai bahasa nasional, dan bahasa asing sebagai bahasa sumber ilmu pengetahuan. Kedudukan tiga bahasa ini akan diperjelas melalui undang-undang dan dilindungi pemakaiannya sehingga tidak saling menerjang dan mengalahkan yang lain.

\section{SIMPULAN}

Geopolitik dibutuhkan oleh setiap negara di dunia untuk memperkuat posisinya terhadap negara lain. Keadaan geografi suatu negara sangat mempengaruhi berbagai aspek dalam penyelenggaraan negara tersebut, seperti pengambilan keputusan, kebijakan politik luar negeri, hubungan perdagangan, juga dalam perencanaan bahasa.Perencanaan bahasa suatu negara sangat penting untuk menjaga keutuhan bangsa tersebut. Peren-canaan yang terdiri dari perencanaan status dan korpus mempengaruhi kedudukan negara tersebut di dunia. Dari beberapa negara yang dijadikan sampel penelitian, didapat simpulan bahwa keadaan geopolitik suatu negara memengaruhi perencanaan bahasa di negara tersebut. Misalnya, kondisi geopolitik di Eropa yang relatif stabil berpengaruh besar terhadap bahasanya sehingga bisa ekspansi bahasa ke negara lain. Oleh karena itu, tidak mengherankan jika bahasa-bahasa Eropa banyak dijadikan bahasa nasional negara lain.

Perencanaan bahasa di Indonesia dimulai ketika dikumandangkannya Sumpah Pemuda oleh para pemuda di Indonesia. Salah satu butir sumpah itu adalah "Kami putra dan putri Indonesia menjunjung bahasa persatuan, bahasa Indonesia." Sejak itu, bahasa Indonesia resmi menjadi bahasa nasional dan bahasa negara Indonesia. Perencanaan bahasa Indonesia secara status terdapat dalam UUD 1945 Pasal 36. Hal itu diperkuat dengan didirikannya lembaga bahasa yang khusus menangani perkembangan bahasa dan sastra yaitu lembaga yang disebut Pusat Bahasa. Dalam perencanaan bahasa, Pusat Bahasa sebagai lembaga resmi yang mengurusi bahasa di Indonesia berperan menjalankan perencanaan korpus melalui berbagai kamus dan aturan bahasa yang dibuatnya sehingga dijadikan rujukan resmi bahasa Indonesia.

\section{DAFTAR PUSTAKA}

Depdiknas. (2009). Peta Bahasa. Jakarta: Pusat Bahasa.

Gadelli, Karl Erland. (1999). "Language Planning: Theory and Practice". Paris: Division Education Sector UNESCO.

Kridalaksana. (1991). "Pendekatan Historis dalam Kajian Bahasa Melayu dan

Bahasa Indonesia" dalam Masa Lampau Bahasa Indonesia: Sebuah Bunga Rampai. Yogyakarta: Penerbit Kanisius.

Moeliono, Anton. (1981). Pengembangan dan Pembinaan Bahasa: Ancangan 
Alternatif di dalam Perencanaan Bahasa. Jakarta: Pusat Bahasa

Muslich, Masnur. (2007). "Dasar-dasar Perencanaan Bahasa". Malang: Universitas Negeri Malang

Fishman, Joshua A. (ed.). (1974). Advanced in Language Planning. The Hague: Mouton.

Haugen, E. (1959). "Planning for Standard Language in Modern Norway." Dalam Anthropological Linguistics, I (3): 8 21. 1966a. "Construction and Reconstruction in Language

Planning: Ivar Aasen's Grammar." Dalam Word, 2 (2): 188 - 207. . (1966) b. "Dialect, Language, Nation." Dalam American Anthropologist, 68 (4): 922 - 935. .1966c. "Linguistic and Language

Planning." Dalam W. Bright (ed.). Sociolingustics: Proceedings of the VCLA Sociolinguistics Conference.

The Huggue: Norton, hlm. 159: 190. (1966) d. Language Conflict and Language Planning: The Case of Modern Norwegian. Cambridge: Harvard University Press.

(1969). "Language Planning, Theory and Practice." Dalam A. Graur (ed.). Actes due Xe Congres International des Linguistic Bucharest. Bucharest: Editions de L'Academic de La Republique de Roumanic, $701-711$. 